\title{
Reducing the Costs of Participation
}

\author{
Joseph D. Giammo \\ University of Arkansas at Little Rock \\ Brian J. Brox \\ Tulane University, New Orleans, Louisiana
}

\begin{abstract}
The authors address the puzzle of why governments have implemented methods of early voting when those methods appear not to have an effect on turnout. Using an aggregate analysis, the authors find that early voting seems to produce a short-lived increase in turnout that disappears by the second presidential election in which it is available. They also address whether the additional costs to government are worth the negligible increase in participation. They conclude that these reforms merely offer additional convenience for those already likely to vote.
\end{abstract}

Keywords: elections and voting behavior; public opinion and political participation; representation and electoral systems; state politics and policy

$\mathrm{O}$ ne of the most significant reforms to the American electoral system in the past thirty years has been the advent of several forms of convenience voting. From no-excuse absentee balloting to early voting and even all-mail elections, it has never been easier for a registered voter in the United States to participate in selecting government officials. In the 2004 U.S. presidential election, thirty states allowed some form of convenience voting (National Association of Secretaries of State n.d.). ${ }^{1}$ These forms of early voting have become quite popular. For example, in the 2002 general election, more than a quarter of California voters voted with no-excuse absentee ballots (Berinsky 2005), while more than a third of voters in Texas made use of in-person early voting (Stein, Leighley, and Owens 2004). Nationwide, more and more voters are taking advantage of these more convenient methods for casting a ballot. In the 1992 presidential election, 8.5 percent of voters used some form of early or absentee voting. That percentage increased to 11.3 percent in $1996,16.4$ percent in 2000 , and 21.7 percent in $2004 .^{2}$ Clearly, as voters see the opportunity for participating in a more convenient fashion, they are increasingly choosing to do so. As a result, it seems unlikely that these innovations will be scaled back (Rosenfield 1994).

The implications of these reforms are significant. For voters, the ability to cast a ballot early reduces the costs of participation, not only by making it more convenient to vote on one's own schedule but also by reducing the amount of information one must consider when deciding for whom to vote. ${ }^{3}$ For parties and candidates, early voting drastically changes the way they run campaigns. As Republican pollster Glen Bolger put it, "You need to divide the electorate into two groups. Run one campaign at early voters and another at Election Day voters," (quoted in Nordlinger 2003, 27). And for society, early voting presumably advances democratic government, not only by making voting easier and more convenient but also by bringing more potential voters to the polls, thus increasing legitimacy.

But in making voting easier and more convenient, society does not reduce the overall costs of participation in any given election. Rather, early voting merely transfers certain costs from the individual to society-in this case, the counties that conduct elections. This transfer of costs begs the question: is it worth the cost? For the proponents of early voting, the answer is certainly yes. These proponents suggest that by making participation easier and more convenient,

\footnotetext{
Authors' Note: Names are arbitrarily listed in reverse alphabetical order - both authors contributed equally to the manuscript. Previous versions of this article were presented at the 2006 Southern Political Science Association annual meeting and the 2007 State Politics and Policy conference. We would like to thank Steve Voss, Jim Battista, Daron Shaw, Danny Hayes, Mark Vail, the participants of the Tulane Political Science Faculty Research Seminar, and the anonymous reviewers for their helpful comments and advice.
} 
turnout will increase (Pennsylvania Election Reform Task Force n.d.; Anonymous 2005; Kenny 2004). Kentucky Secretary of State Trey Grayson suggests that by expanding the use of no-excuse absentee ballots, turnout will increase by giving people additional opportunities to vote and by reducing lines on Election Day (Crowley 2006). Following the implementation of early voting in Illinois, St. Clair County Clerk Bob Delaney said that "the hope is that it will increase voter turnout" (McDermott 2006, C2). And lawmakers in Maryland passed a law in 2005 that would allow for a week of early voting with the intention of increasing turnout in Maryland's elections (Mosk 2006).

Policy makers clearly believe that implementing various forms of convenience voting will improve turnout. If these efforts do lead to increased turnout, many would accept the added cost to society for the added legitimacy conferred by elections with greater turnout. But if, on the other hand, early voting does not increase turnout, then early voting is indeed simply a form of "convenience" voting, and the cost borne by society can be categorized as a "handout" to those individuals already predisposed to vote.

Previous research into early voting has revealed much about who votes early. Specifically, individuals with high interest, strong partisan attachments, and strong ideological alignments are more likely to vote early (Berinsky, Burns, and Traugott 2001; Karp and Banducci 2001; Stein 1998). But people with those attributes are more likely to turn out in general. In this article, we take a different path by looking to see whether the implementation of various forms of convenience voting actually does what its proponents say it will do: increase turnout in the aggregate. We begin by reviewing the theoretical claims as to why turnout should increase with the introduction of convenience voting, and then proceed to discuss previous work on the impact of these reforms on turnout. We then apply these theoretical and empirical insights in the development of a model to test the impact of early voting on aggregate turnout. Our main aim is to see whether turnout increases following the implementation of early voting and, if so, how long the effect persists. We conclude by reviewing our findings as well as discussing a couple of examples of how the costs involved with implementing convenience voting are significant-and perhaps unjustified - if they fail to increase turnout.

\section{The Theory behind Early Voting}

The theoretical basis of research on turnout is that individuals are rational; when faced with the prospect of voting, they undertake a cost/benefit analysis and will choose to participate when the benefits outweigh the costs (Riker and Ordeshook 1968). We take as a given that voting is a low-benefit activity (Aldrich 1993), and much previous research suggests that reducing the costs of participation increases turnout (Dyck and Gimpel 2005; Brady and McNulty 2004; Gimpel and Schuknecht 2003; Southwell and Burchett 2000b; Stein and Garcia-Monet 1997).

As a result, it is easy to understand how the option to vote early should reduce the costs of participation for individuals, both through the reduction of barriers to voting and through its mobilizing effect. On the latter count, if individuals have a few days or a few weeks before the election in which to vote, several things could happen that could mobilize them:

- They might stumble upon an early voting location. This happens more readily in states like Texas and Nevada where early voting locations show up in nontraditional sites like grocery stores, libraries, and shopping malls_-places where people are going for other reasons.

- They might run across others who voted early. These other early voters are likely to tell people that they voted, or to wear the "I Voted" stickers, so that their families, friends, and coworkers will be reminded about the election and the chance to vote early.

- They might encounter news coverage of early voting. News media cover not only the beginning of early voting but also provide turnout estimates during the early voting period. These serve as reminders about the election.

- They might be subject to candidate and party campaigns that encourage people to vote early. Candidates and parties have an incentive to "lock in" votes and will use all of the traditional media-direct mail, television ads, speeches, canvassing - to reach potential early voters. If someone has already chosen to support a candidate, then from the perspective of that candidate, any additional information that comes out over the final days of the campaign will either have no effect or a negative impact on him or her. If candidates and parties can secure those votes early, they avoid the risk that some last-minute revelation will causes the voter to change his or her mind.

In addition, the fact that some appreciable number of people vote early may also shorten lines at the precincts on Election Day itself, thus reducing the costs to people who do not themselves take advantage of the early voting option.

Therefore, the presence of an option to vote early should increase the chances that any given individual will turn out to vote. As a result, states that offer early 
voting options should see higher turnout than those who merely offer Election Day precinct voting, ceteris paribus. But before we turn to that question, we review previous research on the impact of early voting on turnout. As we shall soon see, the straightforward theoretical case that early and convenience voting options should increase turnout is not mirrored by straightforward findings in previous work on individual and aggregate turnout in American elections.

\section{What We Know about Early Voting}

Early work in the area of convenience voting focused on the effects of expanding absentee ballot programs. One such piece is Oliver's (1996) analysis of absentee voting. Oliver showed that the liberalization of absentee voting requirements produces an increase in absentee voting but does not, by itself, increase overall turnout. However, he did find that when liberalized absentee voting requirements are combined with efforts by political parties to encourage the use of absentee ballots, overall turnout does increase. Karp and Banducci (2001) had similar findings; the authors showed that liberal absentee laws do not expand the overall electorate; they just allow those already likely to vote to do so by mail.

A more recent development in the expansion of convenience voting is the advent of in-person early voting. Studies of this form of participation, though generally based on geographically limited data, provide insight into the profile of early voters and their electoral behavior. Stein (1998) showed in his analysis of the 1994 general election in Texas that early voters are distinguished from Election Day voters by attitudinal (rather than demographic) characteristics. Specifically, early voters tend to be strong partisans, strong ideologues, and more interested in politics. These findings are corroborated by Berinsky, Burns, and Traugott (2001) and Karp and Banducci (2001).

On the topic of electoral behavior, many note the fact that early voting radically changes the electorate that parties and candidates must campaign toward (Dyck and Gimpel 2005; Stein, Leighley, and Owens 2004). Yet early voters are not all that different from Election Day voters in terms of voting behavior. Early voters tend to choose candidates based on their party identification (Stein, Leighley, and Owens 2004; Stein 1998) and ideology (Stein, Leighley, and Owens 2004), though they consider group affiliations, issue preferences, and candidate evaluations less than do Election Day voters (Stein, Leighley, and Owens 2004). And the evidence is mixed regarding the impact of early voting on overall turnout, with some saying early voting by itself produces a modest increase (Stein and Garcia-Monet 1997), some saying early voting coupled with mobilization efforts can increase turnout (Stein, Owens, and Leighley 2003; Stein and Garcia-Monet 1997), and some saying it has no effect on turnout (Neeley and Richardson 2001). Generally speaking, it appears that no-excuse absentee voting is less of a boon for turnout than it is a convenience for those who face relatively higher costs when voting in person.

Voting by mail is the latest innovation in the expansion of convenience voting. So far it has been implemented only in Oregon, but in that case, it has entirely replaced in-person voting. As with studies of early voting, research into voting by mail has sought to explore the profile of the voting-by-mail electorate and the basis of their electoral behavior. With respect to the profile of the electorate, Southwell and Burchett (2000a) found that vote-by-mail voters are demographically similar to traditional Election Day precinct voters as well as registered nonvoters. They also noted that vote-by-mail voters are equally informed, educated, and involved when compared to traditional voters but that they are more educated, involved, politically aware, and residentially stable than are registered nonvoters. This assessment is disputed by Berinsky, Burns, and Traugott (2001), who found that voting by mail is largely dependent on the availability of (civic) resources. They suggest that the move to all-mail voting in Oregon has done little to assist those without politically relevant resources while making it easier for those with greater civic skills to remain in the electorate.

Turning to electoral behavior, Southwell and Burchett (2000b) addressed overall turnout in their analysis of primary and general elections in Oregon from 1960 to 1996. They found that all-mail elections increase turnout and estimated that turnout in all-mail elections is 10 percent higher than the "expected turnout" in traditional polling place elections. Berinsky, Burns, and Traugott (2001) generally agreed with this finding, but they noted that the increase in turnout is achieved by making it easier for previous voters to remain in the electorate ("retention") rather than by mobilizing previous nonvoters.

It appears that the consensus among previous research into convenience voting is that no-excuse absentee voting, early voting, and all-mail voting all reduce the 
costs of participation. Beyond that the consensus falls apart. Some argue that the reduction of costs is enough to increase turnout, while others maintain that it requires concurrent efforts on the part of elites to mobilize individuals to produce higher turnout. Still others find no effect at all. At this point it is helpful to consider Berinsky's (2005) point that these forms of convenience voting merely reduce "tangible" barriers to voting but that many "cognitive" barriers still exist. Perhaps most troubling, according to Berinsky, is the fact that cognitive skills and political engagement are unevenly distributed across the electorate. As a result, reducing the tangible costs of participation tends to benefit only the most engaged citizens, thus magnifying existing socioeconomic biases in the electorate. If Berinsky is correct, then convenience voting is more of handout to the resource-rich members of society rather than a worthy effort to improve democracy through expanding the electorate.

\section{The Impact of Early Voting in the Aggregate}

For state and local governments considering the additional cost that would be borne by implementing convenience voting options, the important issue is not how many people make use of options to vote early but rather whether their introduction actually stimulates turnout. After all, if the goal of such measures is to increase turnout by making voting more convenient, it does not actually matter which voters are taking advantage of them, ${ }^{4}$ as long as participation increases. If a large number of habitual voters decide to take advantage of the opportunity to vote earlywhich results in shorter lines on Election Day itself, which in turn reduces the costs of waiting in line for more marginal voters - that would be a victory for these reforms. If, however, all that happens is that some habitual voters shift their voting practices, without any overall increase in turnout, then state and local governments could very likely find better ways to spend their money.

To test for the effect of these policies on aggregate turnout, we randomly selected five hundred counties across the United States. ${ }^{5}$ We then gathered information about the election laws in the relevant states, the timing of the introduction of any methods of convenience voting, ${ }^{6}$ and the turnout in the presidential race for each county over the past nine election cycles. ${ }^{7}$ With these data we perform a multivariate analysis to assess the impact of convenience voting on the change in turnout from the previous presidential election. Using change in turnout, rather than the raw turnout levels, allows us to account for differences that exist in turnout from county to county for reasons that may be related to the decision to allow alternative methods of voting, but not caused by the availability of those methods, as well as to better account for the impact of the introduction and continued use of these methods on turnout in any given election.

Looking at the five hundred counties we selected over the course of eight presidential elections gave us four thousand total cases to evaluate. ${ }^{8}$ We then used ordinary least squares regression with panelcorrected standard errors to estimate the impact of these additional methods of voting on turnout for each of the first three elections in which they were in use. In addition, we controlled for the change in national turnout from the previous presidential election, since changes at the national level would also show up at the local level. ${ }^{9}$ We also controlled for differences on the ballot from the previous election cycle, particularly the presence or absence of a Senate or gubernatorial election. ${ }^{10}$ Since these tend to be the highest-profile elections below the presidential level, the addition or subtraction of a gubernatorial or Senate race on the ballot, when compared to the previous presidential election, might also stimulate or depress turnout. Additionally, the efforts by the campaigns and parties to get their supporters to the polls as well as the perceived benefits of voting may be influenced by the competitiveness of a state, since the Electoral College makes marginal gains in vote totals useless in uncompetitive states. Therefore, we also controlled for the difference in the margin of victory at the state level for the winning presidential candidate from the previous presidential election, expecting that a closer election at the state level should produce higher turnout at the county level. ${ }^{11}$ The results are presented in Table 1.

These results suggest that any gains in turnout that result from making voting more convenient are shortlived. Whether looking only at the introduction of early voting, only at the introduction of no-excuse absentee balloting, or at the introduction of either of these options or the vote-by-mail system now used in Oregon, we found very consistent results. ${ }^{12}$ In two of the three cases, there was a positive and statistically significant increase in aggregate turnout in the first 
Table 1

The Impact of the Introduction of Convenience Voting Methods on Aggregate Turnout at the County Level

\begin{tabular}{lccc}
\hline Variable & Early Voting & No-excuse Absentee Balloting & Any Convenience Voting Option \\
\hline Change in national turnout & $.010^{* *}(.001)$ & $.009^{* *}(.001)$ & $.009^{* *}(.001)$ \\
Change in governor's race & $-.003(.009)$ & $-.003(.010)$ & $-.003(.009)$ \\
Change in Senate race & $-.001(.002)$ & $.000(.002)$ & $-.001(.002)$ \\
Change in margin & $.001^{* *}(.000)$ & $.001^{* *}(.000)$ & $-001^{* *}(.000)$ \\
Early voting offered the first time & $.015^{* *}(.001)$ & - & - \\
Early voting offered the second time & $-.024^{* *}(.007)$ & - & - \\
Early voting offered the third time & $-.004(.009)$ & $-.012(.009)$ & - \\
Absentee balloting offered for the first time & - & $-.019(.011)$ & - \\
Absentee balloting offered for the second time & - & $-.028^{*}(.012)$ & $.015^{* *}(.000)$ \\
Absentee balloting offered for the third time & - & - & $-.022^{* *}(.007)$ \\
Any option offered for the first time & - & $-.005(.008)$ \\
Any option offered for the second time & - & $.001(.001)$ & $.000(.003)$ \\
Any option offered for the third time & $-.000(.003)$ & 3,998 & 3,998 \\
Constant & $3,990^{\mathrm{a}}$ & .379 & .378 \\
Number of cases & & .374 & - \\
$R^{2}$
\end{tabular}

Source: See notes 6 and 7.

For descriptive statistics for each of the early voting, absentee balloting, and any option variables, see Appendix C.

a. This analysis contains eight fewer cases than the others because information about when early voting was introduced in Hawaii was not available on the state's Web page and repeated attempts to contact the Secretary of State's office via e-mail and phone calls were unsuccessful. The one county from Hawaii in the sample, therefore, was excluded from this analysis.

$* p<.05 . * * p<.01$.

presidential election after the rules were changed to make voting more convenient, with a gain of roughly one and a half percentage points. This gain, however, was negated in the next election, with a statistically significant average decrease in turnout of roughly two percentage points for both models. Turnout then stabilized by the third presidential election in which voters had these options.

In the case of no-excuse absentee ballots, turnout held steady in the first two elections after it was introduced but then dropped by nearly 3 percentage points in the third election. This suggests that voters may react positively to the novelty of being able to vote in the weeks leading up to the election or being able to mail in ballots at their own convenience, but once that novelty wears off, they are no longer mobilized by the convenience of these methods. It is likely that the unveiling of such options is accompanied by a great deal of publicity, with an emphasis on the convenience to the voter and the expected boost in participation that should accompany these new policies. Such publicity, along with a desire to try these new methods, could easily account for the statistically significant but substantively slight average gain in the first presidential election in which voters get a chance to use them. However, with the novelty gone and likely far less emphasis by the media or government officials on the availability of such options after the first election during which voters can opt for these methods, the stimulus to use them seems to have disappeared.

In fact, these results suggest that the impact of these policies is to change potential voters' calculations about the inherent benefits of voting, rather than the costs. The reduction of costs, after all, is constant. It is just as convenient to vote early the second time as it was the first. If anything, it should even be more convenient, since any problems from the first time are likely to have been worked out, and voters who made use of early voting options in the previous election have already paid the cost of figuring out how to use them. The benefits, however-particularly the benefits of trying a novel method of voting-would decrease after the first use.

\section{Discussion and Conclusion}

Our results point to several conclusions about early voting. First, implementing early voting procedures does not, by itself, increase turnout. Our finding that overall turnout does not increase with early voting is consistent with the findings of Karp and Banducci (2001) and Neeley and Richardson (2001). 
Surprisingly, we find that this is true regardless of the type of early voting that voters have access to.

On one hand, one might have expected that inperson early voting would have a stronger positive impact on turnout than no-excuse absentee balloting. While voting by absentee ballot requires the same forethought and effort that prevents some from registering to vote or turning out on Election Day itself, in-person early voting is a form of participation that many people are likely to encounter as they go about their daily lives, especially those who live in states that place early voting locations in nontraditional sites such as libraries, shopping malls, and grocery stores. However, counties that offer in-person early voting show no long-term increase in turnout.

On the other hand, one might have expected noexcuse absentee balloting to have a stronger positive impact on turnout since many states provide the option of acquiring permanent absentee status. Once registered, no further action would be required by the voter to receive ballots. Yet not only do we not find a statistically significant increase in turnout upon the introduction of no-excuse absentee balloting, but we also find that turnout in fact declines by the third election after its introduction. This could be a function of habitual voters changing to the new method of voting, then dropping out of the electorate upon missing an election as many states remove a voter's status as a permanent absentee voter with just one missed election. ${ }^{13}$ In any event, there appears to be, at best, a minor and short-lived boost in turnout that disappears by the second or third election in which it is offered.

This begs the question, though, of whether the money spent by counties to implement convenience voting methods is worth it. A couple of examples may serve to illustrate. The county of Mecklenburg, North Carolina, has budgeted just over $\$ 300,000$ for 2008 for expenses related to early voting, compared to approximately $\$ 650,000$ for Election Day expenses in the same year (Mecklenburg County, North Carolina n.d.). That Election Day spending supports 193 precincts, at a cost of roughly $\$ 3,350$ per precinct. If that $\$ 300,000$ were spent on Election Day, rather than on early voting, the county could undoubtedly afford to significantly increase the number of precincts available to voters on Election Day, a change that shows much greater promise for actually increasing turnout by reducing the distance voters must travel to the polls (Gimpel and Schuknect 2003; Dyck and Gimpel 2005; Haspel and Knotts 2005).
Similarly, Pulaski County, Arkansas, budgets $\$ 375$ per day, per early voting site, just to pay for staffing, compared to $\$ 570$ per site on Election Day itself (Susan Inman, Pulaski County elections director, telephone interview, February 15, 2008). With eight sites, open for twelve days each, Pulaski County spends $\$ 36,000$ for each election to provide voters with the opportunity to vote early. If that $\$ 36,000$ were instead spent on Election Day, it would pay for staff for sixtythree more precincts, which would increase by almost half the number of precincts available to voters on that day. Not only would that make voting on Election Day more convenient by shortening the average distance from each voter's residence to his or her polling place, but it would also reduce lines at those polling places, enough to at least offset the influx of voters who would have otherwise voted early.

As noted earlier, however, early voting is unlikely to disappear anytime soon. Yet its promise of increasing turnout in American elections appears unfulfilled. While elected officials are in no rush to scale back the convenience voting option that serves as a true "convenience" for habitual voters, the search for reforms that will truly reduce the barriers to participation and increase turnout will have to continue.

\section{Appendix A Variable Descriptions}

Change in county turnout-calculated by taking the turnout level in the country for each case and subtracting the turnout in that same county in the previous presidential election.

Change in national turnout-calculated by taking the national turnout for the presidential election during the year in which each case took place and subtracting the national turnout in the previous presidential election.

Change in governor's race-coded as - 1 for cases in which voters in that county had an opportunity to vote in a gubernatorial election during the previous presidential election year but not in the current one, coded as 0 for cases in which there was either a gubernatorial election on the ballot in both the current and previous presidential election year or in neither, and coded as 1 for cases in which there was no gubernatorial election on the ballot in the previous presidential election year but was one in the current year.

Change in Senate race-coded as -1 for cases in which voters in that county had an opportunity to vote in a Senate 


\section{Appendix A (continued)}

election during the previous presidential election year but not in the current one, coded as 0 for cases in which there was either a Senate election on the ballot in both the current and previous presidential election year or in neither, and coded as 1 for cases in which there was no Senate election on the ballot in the previous presidential election year but was one in the current year.

Change in margin-calculated by taking the margin of victory in that state in the previous presidential election and subtracting the margin of victory in that state in the current presidential election.

Early voting offered the first time-coded as 1 for cases in which voters in that county had their first chance to vote early in person during that presidential election and 0 for all others. The same logic was used to code the "second time" and "third time" variables.

Absentee balloting offered for the first time - coded as 1 for cases in which voters in that county had their first chance to vote using a no-excuse absentee ballot during that presidential election and 0 for all others. The same logic was used to code the "second time" and "third time" variables.

Any option offered for the first time-coded as 1 for cases in which voters had their first chance to vote early in person, their first chance to vote using a no-excuse absentee ballot, or their first chance to vote using Oregon's vote by mail system and 0 for all others. The same logic was used to code the "second time" and "third time" variables.

\section{Appendix B} Distribution of Counties by State

\begin{tabular}{lrlr}
\hline State & $\begin{array}{c}\text { Number } \\
\text { of Counties }\end{array}$ & State & $\begin{array}{c}\text { Number of } \\
\text { Counties }\end{array}$ \\
\hline Alabama & 12 & Nebraska & 18 \\
Alaska & 3 & Nevada & 3 \\
Arkansas & 15 & New Hampshire & 2 \\
California & 4 & New Jersey & 4 \\
Colorado & 15 & New Mexico & 3 \\
Connecticut & 2 & New York & 9 \\
Florida & 13 & North Carolina & 15 \\
Georgia & 27 & North Dakota & 11 \\
Hawaii & 1 & Ohio & 20 \\
Idaho & 7 & Oklahoma & 14 \\
Illinois & 21 & Oregon & 3 \\
Indiana & 14 & Pennsylvania & 13 \\
Iowa & 15 & South Carolina & 5 \\
Kansas & 18 & South Dakota & 11 \\
Kentucky & 21 & Tennessee & 15 \\
\hline
\end{tabular}

Appendix B (continued)

\begin{tabular}{lrlr}
\hline Louisiana & 9 & Texas & 47 \\
Maine & 2 & Utah & 2 \\
Maryland & 3 & Vermont & 1 \\
Massachusetts & 2 & Virginia & 17 \\
Michigan & 11 & Washington & 7 \\
Minnesota & 12 & West Virginia & 12 \\
Mississippi & 12 & Wisconsin & 5 \\
Missouri & 13 & Wyoming & 2 \\
Montana & 9 & Total & 500 \\
\hline
\end{tabular}

Note: A complete list of the counties used in the analysis is available from the authors.

\section{Appendix C \\ Descriptive Statistics for the Introduction of Convenience Voting Methods in the Analyses in Table 1}

\begin{tabular}{lc}
\hline & $\begin{array}{c}\text { Number of } \\
\text { Cases Coded } \\
1 \text { in the } \\
\text { Analysis }\end{array}$ \\
Variable & 301 \\
\hline Early voting offered the first time & 183 \\
Early voting offered the second time & 148 \\
Early voting offered the third time & 161 \\
Absentee balloting offered for the first time & 118 \\
Absentee balloting offered for the second time & 72 \\
Absentee balloting offered for the third time & 352 \\
Any option offered for the first time & 233 \\
Any option offered for the second time & 183 \\
Any option offered for the third time & \\
\hline
\end{tabular}

\section{Notes}

1. Of the thirty states, twenty-seven allow voters to cast ballots early in person, twenty allow voters to cast ballots early by mail, and one (Oregon) conducts its elections entirely by mail. Washington allows counties to choose to hold vote-by-mail elections (National Association of Secretaries of State n.d.).

2. Data are from the Associated Press summaries of early and absentee balloting in 2002 and 2006.

3 . By voting early, voters by definition truncate the campaign, thus making it unnecessary (and impossible) to consider any information raised by the campaigns between the date of early voting and Election Day.

4. In a separate analysis-not presented-we estimated the impact of early and convenience voting options using individuallevel data from the 2004 National Election Studies (NES). Our findings suggest that convenience voting has no significant impact on turnout. This null finding held in subsequent analyses in which the various forms of convenience voting were considered separately (in-person early voting versus mail balloting) as well as in analyses that subdivided the NES sample by ex ante propensity to vote. Thus, we feel confident in concluding that, at the individual level, turnout is not influenced by the presence of convenience voting options but instead by traditional variables, such as income, 
education, partisan intensity, political activity, political knowledge, and direct contact by the campaigns. The results of these analyses are available from the authors upon request.

5. For a breakdown of the distribution of counties by states, see Appendix B.

6. Information about the early voting and absentee ballot laws for each state was initially taken from a list compiled by Paul Gronke at Reed College (Early Voting Information Center n.d.). Verification of this information, as well as information about the dates on which any such reforms were implemented, was made through phone calls or e-mails to the Secretary of State's Office or Elections Division of each state's government during the summer of 2006.

7. Since turnout figures released by state and local governments are almost all calculated as a percentage of registered voters, rather than as a percentage of eligible voters or the adult population, turnout was calculated by taking the total number of votes cast for president in each county (Scammon 1973; Scammon and McGillvray 1977, 1981, 1985, 1989, 1993; Scammon, McGillvray, and Cook 1998, 2001, 2006) divided by the census estimate of the population over the age of eighteen in that county (U.S. Census Bureau 1972, 1976, 1980, 1984, 1988, 1992, 1996, 2000, 2004). While this measure underestimates turnout, both by excluding undervotes and overvotes from the numerator as well as by including ineligible voters in the denominator, it is hard to imagine how that the error in the measure would be correlated with the decision to introduce early voting or no-excuse absentee ballot provisions in a given location.

8. Change in turnout, both at the national and county levels, was calculated by taking the turnout level for each case and subtracting the turnout for the same geographic unit in the previous presidential election.

9. This measure takes the place of dummy variables for each election year, since the change in national turnout is unique for each election. It provides more information than such dummy variables, since it allows for meaningful ordering of years.

10. While Senate elections are obviously staggered in such a way that, barring a vacancy, there is no Senate race on the ballot in any given state in one out of every three presidential elections, the fact that governors generally serve four-year terms means that it is much less common for voters to vote in a gubernatorial election in one presidential election year and not have a chance to do so in the next, or vice versa. However, several states changed their constitutions to lengthen the governor's term from two to four years during the time frame of the study, which in those cases may have created an instance in which there was a difference from the previous presidential election year ballot.

11. For a full description of the way variables were coded for the analysis, see Appendix A.

12. There were too few cases (six total) in which Oregon's vote-by-mail system was an option, so no separate analysis of the impact of this system was conducted.

13. We thank one of the anonymous reviewers for this insight.

\section{References}

Aldrich, John H. 1993. Rational choice and turnout. American Journal of Political Science 37:246-78.

Anonymous. 2005. Shop and vote. Winston-Salem Journal, December 13, sec. A.
Berinsky, Adam J. 2005. The perverse consequences of electoral reform in the United States. American Politics Research 33:471-91.

Berinsky, Adam J., Nancy Burns, and Michael W. Traugott. 2001. Who votes by mail? A dynamic model of the individual-level consequences of voting-by-mail systems. Public Opinion Quarterly 65:178-97.

Brady, Henry E., and John E. McNulty. 2004. The costs of voting: Evidence from a natural experiment. Paper presented at the annual meeting of the Midwest Political Science Association, April 15-18, Chicago.

Crowley, Patrick. 2006. Grayson wants to expand absentee voting. The Courier-Journal, December 21.

Dyck, Joshua J., and James G. Gimpel. 2005. Distance, turnout, and the convenience of voting. Social Science Quarterly 86:531-48.

Early Voting Information Center. n.d. Absentee and early voting laws. http://www.earlyvoting.net/states/abslaws.php (accessed July 15, 2008).

Gimpel, James G., and Jason E. Schuknecht. 2003. Political participation and the accessibility of the ballot box. Political Geography 22:471-88.

Haspel, Moshe, and H. Gibbs Knotts. 2005. Location, location, location: Precinct placement and the costs of voting. Journal of Politics 67:560-73.

Karp, Jeffrey A., and Susan A. Banducci. 2001. Absentee voting, mobilization, and participation. American Politics Research 29:183-95.

Kenny, Megan. 2004. More early voting expected, Putnam officials say absentee votes hit record in 2000. Charleston Daily Mail, April 15, sec. A.

McDermott, Kevin. 2006. Early-voting law in Illinois begins with March primary: Legislators hope the new format will save the state money as well as increase voter turnout. St. Louis PostDispatch, January 29, sec. C.

Mecklenburg County, North Carolina. n.d. FY 2008 recommended budget. http://www.charmeck.org/Departments/County+ Managers+Office/Business+Management/home.htm (accessed July 15, 2008).

Mosk, Matthew. 2006. Md. GOP says voting law gives Democrats an edge; Democrats seen to have an edge. Washington Post, April 5, sec. A.

National Association of Secretaries of State. n.d. Early voting laws by state. http://nass.org/index.php?option=com_docman \&task=doc_download\&gid=33 (accessed July 15, 2008).

Neeley, Grant W., and Lilliard E. Richardson Jr. 2001. Who is early voting? An individual level examination. Social Science Journal 38:381-92.

Nordlinger, Gary. 2003. Early voting: How it's changing campaign strategies, timing and costs. Campaigns \& Elections 24:27-29.

Oliver, J. Eric. 1996. The effects of eligibility restrictions and party activity on absentee voting and overall turnout. American Journal of Political Science 40:498-513.

Pennsylvania Election Reform Task Force. n.d. Final report on Executive Order 2004-11. http://www.dos.state.pa.us/election _reform/lib/election_reform/PERTF_Final_Report_051705_ Website.pdf (accessed July 15, 2008).

Riker, William H., and Peter C. Ordeshook. 1968. A theory of the calculus of voting. American Political Science Review 62:25-42.

Rosenfield, Margaret. 1994. Early voting. Washington, DC: National Clearinghouse on Election Administration, Federal Election Commission. 
Scammon, Richard M. 1973. America Votes 10: A handbook of contemporary American election statistics, 1972. Washington, DC: Governmental Affairs Institute, Congressional Quarterly.

Scammon, Richard M., and Alice McGillvray. 1977. America Votes 12: A handbook of contemporary American election statistics, 1976. Washington, DC: Elections Research Center, Congressional Quarterly.

Scammon, Richard M., and Alice McGillvray. 1981. America Votes 14: A handbook of contemporary American election statistics, 1980. Washington, DC: Elections Research Center, Congressional Quarterly.

Scammon, Richard M., and Alice McGillvray. 1985. America Votes 16: A handbook of contemporary American election statistics, 1984. Washington, DC: Elections Research Center, Congressional Quarterly.

Scammon, Richard M., and Alice McGillvray. 1989. America Votes 18: A handbook of contemporary American election statistics, 1988. Washington, DC: Elections Research Center, Congressional Quarterly.

Scammon, Richard M., and Alice McGillvray. 1993. America Votes 20: A handbook of contemporary American election statistics, 1992. Washington, DC: Elections Research Center, Congressional Quarterly.

Scammon, Richard M., Alice McGillvray, and Rhodes Cook. 1998. America Votes 22: A handbook of contemporary American election statistics, 1996. Washington, DC: Congressional Quarterly.

Scammon, Richard M., Alice McGillvray, and Rhodes Cook. 2001. America Votes 24: A handbook of contemporary American election statistics, 2000. Washington, DC: CQ Press.

Scammon, Richard M., Alice McGillvray, and Rhodes Cook. 2006. America Votes 26: A handbook of contemporary American election statistics, 2003-2004. Washington, DC: CQ Press.

Southwell, Priscilla L., and Justin I. Burchett. 2000a. Does changing the rules change the players? The effect of all-mail elections on the composition of the electorate. Social Science Quarterly 81:837-45.

Southwell, Priscilla L., and Justin I. Burchett. 2000b. The effect of all-mail elections on voter turnout. American Politics Quarterly 28:72-79.

Stein, Robert M. 1998. Early voting. Public Opinion Quarterly 62:57-69.

Stein, Robert M., and Patricia A. Garcia-Monet. 1997. Voting early but not often. Social Science Quarterly 78:657-71.

Stein, Robert M., Jan Leighley, and Christopher Owens. 2004. Voting, early voting and the determinants of vote choice: Is timing everything? Paper presented at the annual meeting of the Midwest Political Science Association, April 15-18, Chicago.
Stein, Robert M., Chris Owens, and Jan Leighley. 2003. The role of candidates and parties in linking electoral reforms with voter participation. Paper presented at the annual meeting of the Midwest Political Science Association, April 3-6, Chicago.

U.S. Census Bureau. 1972. Estimates of the population of counties in the United States by age, sex, and race: July 1, 1972. In Estimates of the intercensal population of counties 1970-1979. http://www.census.gov/popest/archives/pre-1980/co-asr7079.html (accessed July 15, 2008).

U.S. Census Bureau. 1976. Estimates of the population of counties in the United States by age, sex, and race: July 1, 1976. In Estimates of the intercensal population of counties 19701979. http://www.census.gov/popest/archives/pre-1980/coasr-7079 .html (accessed July 15, 2008).

U.S. Census Bureau. 1980. Estimates of the population of counties in the United States by age, sex, and race: July 1, 1980. In Estimates of the intercensal population of counties 1980-1989. http://www.census.gov/popest/archives/1980s/PE-02.html (accessed July 15, 2008).

U.S. Census Bureau. 1984. Estimates of the population of counties in the United States by age, sex, and race: July 1, 1984. In Estimates of the intercensal population of counties 1980-1989. http://www.census.gov/popest/archives/1980s/PE-02.html (accessed July 15, 2008).

U.S. Census Bureau. 1988. Estimates of the population of counties in the United States by age, sex, and race: July 1, 1988. In Estimates of the intercensal population of counties 19801989. http:// www.census.gov/popest/archives/1980s/PE02.html (accessed July 15, 2008).

U.S. Census Bureau. 1992. Population estimates for counties by age group: July 1, 1992. In Estimates of the population of counties by age, sex, race and Hispanic origin: 1990 to 1999. http:// www.census.gov/popest/archives/1990s/CO-99-13.html (accessed July 15, 2008).

U.S. Census Bureau. 1996. Population estimates for counties by age group: July 1, 1996. In Estimates of the population of counties by age, sex, race and Hispanic origin: 1990 to 1999. http://www.census.gov/popest/archives/1990s/CO-9913.html (accessed July 15, 2008).

U.S. Census Bureau. 2000. Population estimates for counties by age group: July 1, 2000. In Annual estimates of the population by selected age groups and sex for counties: April 1, 2000 to July 1, 2004. http://www.census.gov/popest/counties/asrh/ CC-EST2004-agesex.html (accessed July 15, 2008).

U.S. Census Bureau. 2004. Population estimates for counties by age group: July 1, 2004. In Annual estimates of the population by selected age groups and sex for counties: April 1, 2000 to July 1, 2004. http://www.census.gov/popest/counties/asrh/ CC-EST2004-agesex.html (accessed July 15, 2008). 